\title{
Atlantic cod and snow crab predator-prey size relationship in the Gulf of St. Lawrence, Canada
}

\author{
Denis Chabot ${ }^{1, *}$, Bernard Sainte-Marie ${ }^{1}$, Karine Briand ${ }^{1,2,4}$, John Mark Hanson ${ }^{3}$ \\ ${ }^{1}$ Direction des sciences halieutiques et de l'aquaculture, Institut Maurice-Lamontagne, Pêches et Océans Canada, C.P. 1000, \\ Mont-Joli, Quebec G5H 3Z4, Canada \\ ${ }^{2}$ ISMER, Université du Québec à Rimouski, 300 allée des Ursulines, Rimouski, Quebec G5L 3A1, Canada \\ ${ }^{3}$ Gulf Fisheries Centre, Fisheries and Oceans Canada, P.O. Box 5030, Moncton, New Brunswick E1C 9B6, Canada
}

${ }^{4}$ Present address: SPC Headquarters, BP D5, 98848 Noumea Cedex, 95 Promenade Roger Laroque, Anse Vata, New Caledonia

\begin{abstract}
Atlantic cod Gadus morhua stomach contents (n = 30 973, including 28377 non-empty stomachs) and morphometric measurements on live snow crab Chionoecetes opilio and cod were examined to assess the predator-prey relationship between these 2 species. The most common snow crab instars found in cod stomachs were III and V ( 6 to 8 and $\sim 12$ to $16 \mathrm{~mm}$ carapace width [CW], respectively) in the northern Gulf of St. Lawrence (GSL) and VI and VII ( 17 to 23 and $\sim 23$ to $31 \mathrm{~mm}$ CW, respectively) in the southern GSL. A significant positive relationship was found between cod length and the largest and smallest CW of snow crab ingested by cod. Positive relationships were also found between gape width and body length in cod and between 3 measures of size (maximum span, width at rest, length at rest) and CW in snow crab. Snow crab length at rest was closely related to cod gape width, suggesting that the largest snow crab ingested by cod must be attacked from the side. There appears to be a plateau at $65.1 \mathrm{~mm}$ in the relationship between maximum snow $\mathrm{crab} \mathrm{CW}$ and cod length, caused by the absence of large (adolescent and adult) male snow crab in cod stomachs. Other studies have found recently moulted, soft-shell snow crabs in cod stomachs, but this appears to be rare. Thus, snow crabs are susceptible to predation by cod mostly for the first 4 yr of postsettlement in the GSL. Any effect of cod predation on the snowcrab fishery would be felt 6 to $11 \mathrm{yr}$ later, given growth models established for the GSL.
\end{abstract}

KEY WORDS: Chionoecetes opilio · Gadus morhua · Gape width · Prey selection

\section{INTRODUCTION}

Vast ecologically and economically important expanses of the shelves of the North Atlantic and North Pacific have undergone major changes in ecosystem structure in recent decades (Benson \& Trites 2002, Beamish et al. 2004, Choi et al. 2005, Savenkoff et al. $2007 a, b)$. One conspicuous feature of these changes was a switch between groundfish and large decapod crustaceans as dominant species in bottom communities. Notably, the abundance of the commercially exploited snow crab Chionoecetes opilio may have varied inversely to that of cod in both oceans (Orensanz et al. 2004, Frank et al. 2005). The relative roles of top- down and bottom-up controls in operating these ecosystem shifts are still being debated (Zheng \& Kruse 2006, Greene \& Pershing 2007). Resolution of this issue requires knowledge of species biology and interactions, including predatory-prey relationships.

Snow crab populations and fisheries are characterized by large interannual variation in numbers and landings (Conan et al. 1996, Caddy et al. 2005, Zheng $\&$ Kruse 2006). This variation may be the result of density-dependent mechanisms such as variability in egg production and fertilization success and/or cannibalism of older on younger cohorts (Conan et al. 1996, Sainte-Marie et al. 1996, 2002, Caddy et al. 2005). However, other mechanisms may also be involved. For 
instance, snow crabs are stenothermic and are found in greatest numbers at bottom-water temperatures between -1 and $4^{\circ} \mathrm{C}$ (Slizkin 1982, Squires 1990). Therefore, changes in water temperature are likely to result in changes in crab abundance and habitat range (Tremblay 1997, Sainte-Marie \& Gilbert 1998, Orensanz et al. 2004). Interactions between climate and physical oceanography can also influence food supply as well as larval production, distribution and survival (Rosenkranz et al. 2001, Zheng \& Kruse 2006).

Many authors have proposed that predation can also influence distribution and abundance of snow crab. It has been hypothesized that cod (Gadus morhua in the Atlantic, G. macrocephalus in the Pacific) can regulate snow crab populations (Bailey 1982, Tremblay 1997, Orensanz et al. 2004). Two studies suggest the increase in the biomass and geographic range of snow crab observed in the 1990s in eastern Canada was due to the collapse of Atlantic cod stocks, which was presumed to result in a major reduction in total predation mortality for the snow crab populations (Worm \& Myers 2003, Frank et al. 2005). However, studies based solely on correlations are insufficient to demonstrate top-down control (Hanson \& Lanteigne 2000, Davis et al. 2004). The effect of predation by cod on snow crab population dynamics depends on several factors, including the relative abundance of predators and prey, the degree of spatial and temporal overlap between both species, the importance of the prey in the predator's diet, and the relationship between predator size and prey size. Few of these factors have been dealt with in studies invoking top-down effects between cod and snow crab abundance.

Both species of cod can grow up to well over $1 \mathrm{~m}$ in length (Scott \& Scott 1988, Kimura et al. 1993, Bigelow \& Schroeder 2002, Roberson et al. 2005). Cod diet is strongly influenced by body size: small cod eat a large proportion of small invertebrates, whereas large cod eat larger prey and are more piscivorous (Lilly 1991, Hanson \& Chouinard 2002, Link \& Garrison 2002). There is a large potential for interactions between cod and snow crab on the basis of size. In eastern Canada, snow crabs settle on the bottom at about $3 \mathrm{~mm}$ carapace width (CW) and grow up to a maximum of about $80 \mathrm{~mm} \mathrm{CW}$ for adult females and about $150 \mathrm{~mm} \mathrm{CW}$ for adult males through successive moults (Sainte-Marie et al. 1995, Alunno-Bruscia \& Sainte-Marie 1998, Comeau et al. 1998). Larger cod occupy deeper waters than smaller cod (Hanson 1996, Swain et al. 1998), which may result in a greater degree of spatial and temporal overlap between large cod and snow crab than between small cod and snow crab.

Relatively little is known of the predator-prey relationship between cod and snow crab, even though this is a crucial piece of information for validation of postu- lated top-down controls of snow crab populations. In eastern Canada, the range of snow crab sizes found in cod stomachs was 6 to $70 \mathrm{~mm} \mathrm{CW}$ (Waiwood \& Elner 1982, Robichaud 1985, Robichaud et al. 1991), although a few large (80 to $110 \mathrm{~mm} \mathrm{CW}$ ) but soft-shell male snow crabs were observed in cod stomachs by Robichaud et al. (1991). There was a tendency for larger cod to eat a larger range of crab sizes, but no clear predator-prey size relationship was established. Similarly, cod stomachs from the eastern Bering Sea contained snow crab of 3 to $70 \mathrm{~mm} \mathrm{CW}$, although most snow crab eaten by cod measured 5 to $35 \mathrm{~mm} \mathrm{CW}$ (Livingston 1989, Orensanz et al. 2004), with a tendency for $\mathrm{cod} \geq 60 \mathrm{~cm}$ to eat larger snow crab than smaller cod (Livingston 1989).

In this study we address the issue of what sizes of snow crab are most vulnerable to consumption by Atlantic cod and the basis for this size-selective predation. This is paramount to assess the possible consequences of cod predation on snow crab populations. We use a large database of cod stomachs collected in the Gulf of St. Lawrence (GSL) system over a period of $>10 \mathrm{yr}$ to describe the predator-prey relationship between cod and snow crab. Hitherto undescribed morphometric measurements on snow crab and cod are used to evaluate the limits between the size of cod predators and the size of their snow crab prey.

\section{MATERIALS AND METHODS}

Study area and stomach collection. The GSL is a semi-enclosed sea of approximately $226000 \mathrm{~km}^{2}$ (Koutitonsky \& Bugden 1991) situated in eastern Canada (Fig. 1). It is home to 2 cod stocks during summer and autumn. One stock spawns and feeds in the northern part of the GSL (NGSL, Northwest Atlantic Fisheries Organization [NAFO] Divisions $3 \mathrm{Pn}, 4 \mathrm{R}$ and $4 \mathrm{~S}$ ). The second stock is found in the southern GSL (SGSL), NAFO Division 4T (Fig. 1). Both stocks leave the GSL in late autumn and spend the winter months in the Laurentian Channel, south of Newfoundland and east of Nova Scotia (Chouinard \& Fréchet 1994, Swain et al. 1998, Castonguay et al. 1999, Comeau et al. 2001). Snow crab is abundant in both the NGSL and SGSL, sustaining important and lucrative fisheries.

A total of 30973 cod Gadus morhua stomachs (including 2596 empty stomachs, 8.4\%) were collected during numerous research and commercial fishing-vessel surveys between 1987 and 2003. Cod stomachs were collected during annual research trawl surveys in August and early September from 1993 to 2003 for the NGSL, and in September 1987, 1990 to 1995 and 1999 to 2003 for the SGSL. In both areas, cod stomachs were also collected by commercial trawlers as part of the mo- 


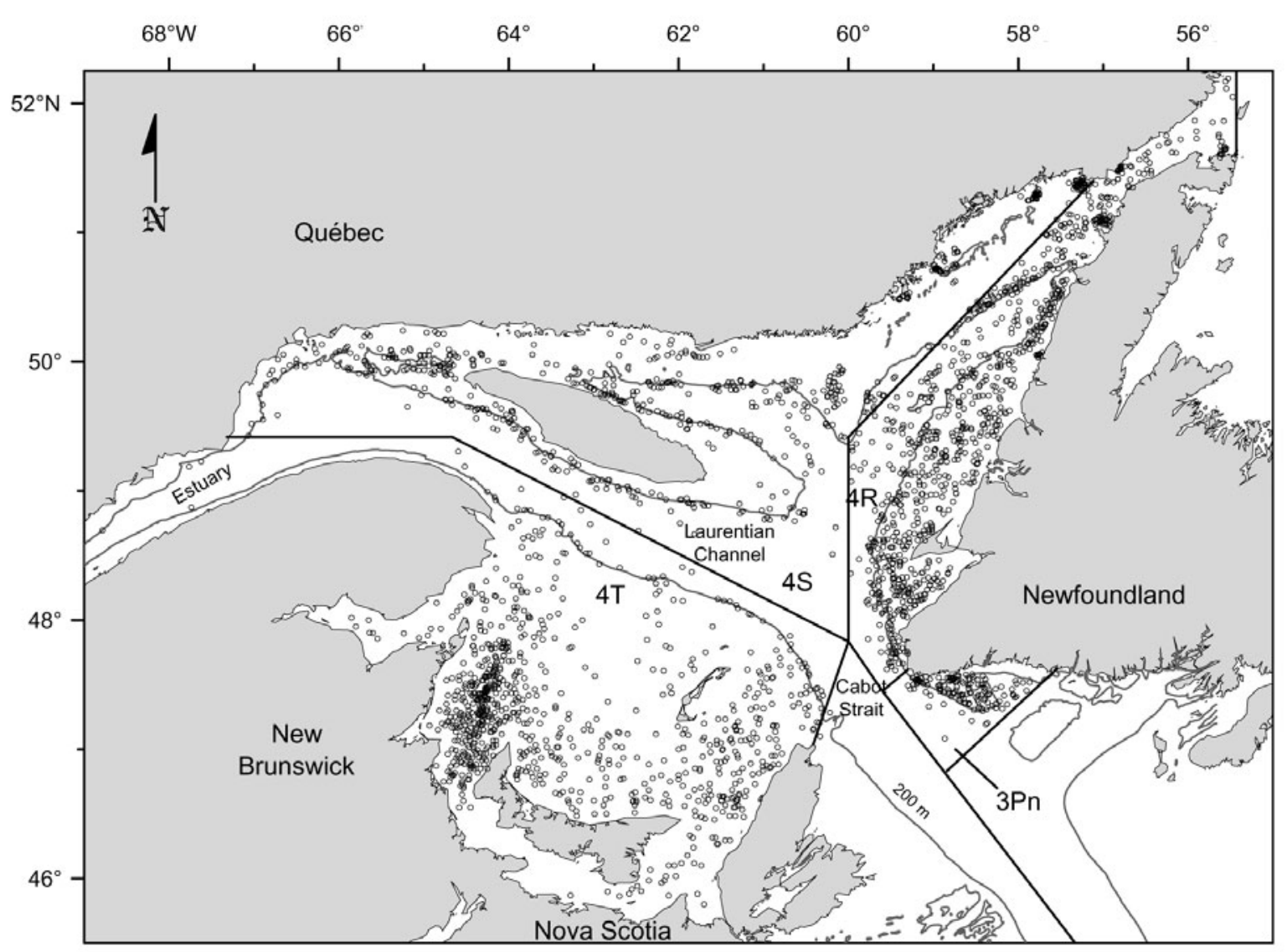

Fig. 1. Gadus morhua. Map of Gulf of St. Lawrence showing Northwest Atlantic Fisheries Association fishing divisions and the positions where cod stomachs were sampled (circles). Divisions 4R, 4S and 3Pn together correspond to the northern Gulf of St. Lawrence (NGSL), whereas area 4T corresponds to the southern Gulf of St. Lawrence (SGSL)

bile-gear sentinel fishery program, in which commercial fishers provided data for scientific investigations by fishing according to instructions from researchers of the Canadian Department of Fisheries and Oceans (e.g. set locations, set and gear characteristics, biological measurements and samples taken, etc.). In the NGSL, fixed gear commercial fishers also sampled cod stomachs as part of the sentinel fishery program. In the SGSL, additional stomachs came from various sources that did not always cover the entire area (for details see Hanson \& Chouinard 2002). Specifics on the sources of stomach samples (ship and gear type, stratification strategy for stomach collection, etc.) are summarized in Tables A1 \& A2 of the Appendix (available at www.int-res.com/ articles/suppl/m363p227_app.pdf). Because of the migratory patterns of cod in the GSL, but also in part due to the dates of the surveys, 93 and $97 \%$ of the stomachs were sampled from July to October in the NGSL and SGSL, respectively. Sample sizes for each year and month are given in Table A3 (available at www.int-res. com/articles/suppl/m363p227_app.pdf).

Cod were weighed $(M$, wet mass $\pm 1 \mathrm{~g})$ and measured (FL, fork length $\pm 0.5 \mathrm{~cm}$, except in the NGSL, where it was $\pm 0.1 \mathrm{~cm}$ after 1994) at sea. In the NGSL, stomachs were excised and frozen at sea, except for the fixed-gear sentinel fishery, in which whole fish were kept on ice for a few hours before stomachs were excised and frozen. In the SGSL, individual fish were usually placed into separate plastic bags and frozen on the ship and sampled in the laboratory. For the sentinel fishery program and the sampling of commercial catches in the SGSL, excised stomachs or whole fish were kept on ice for up to $12 \mathrm{~h}$ before being frozen. After returning from each survey or trip at sea, stomachs or fish were kept at $-40^{\circ} \mathrm{C}$ until the stomachs were analyzed.

Cod stomach analysis. The stomachs were thawed, mucus was removed and total stomach content was weighed. Prey were then identified to the lowest practical taxonomic level and weighed (blotted wet mass $\pm 0.01 \mathrm{~g}$ in NGSL, $\pm 0.0005 \mathrm{~g}$ in SGSL). For all years of sampling in the NGSL, CW of up to 8 randomly chosen crabs per stomach was measured to the nearest $0.01 \mathrm{~mm}$ using a Vernier caliper. For the SGSL, CW of all identifiable snow crabs Chionoecetes opilio was measured to the nearest $1 \mathrm{~mm}$ from 1999 to 2003 only. 
Based on results from the SGSL, we estimate that only $\sim 29$ stomachs from the NGSL contained $>8$ measurable snow crabs and only $\sim 73$ snow crabs were missed $(2.7 \%$ of the number of snow crabs that were measured). Both sexes of snow crab have very similar sizefrequency distributions up $\sim 32 \mathrm{~mm} \mathrm{CW}$ (see their Fig. 1 in Lovrich et al. 1995), and crabs were not discriminated by sex in cod stomachs. Frequency distributions of observed CWs were used to assess instars. Very small instars (I to IV) were considered sedentary (not involved in seasonal migrations) by Lovrich et al. (1995), which may have an impact on vulnerability to predation.

Morphometric measurements. CW was used for convenience in describing the predator-prey relationship, but CW is likely not the limiting factor when cod ingest snow crab. Alternatives are width at rest, maximum span, carapace length (CL) and length at rest. During October 2005, we collected crabs from the St. Lawrence Estuary and selected individuals to cover the available range of body sizes for each sex. Using a Vernier caliper and measuring to the nearest $0.01 \mathrm{~mm}$, we determined $\mathrm{CW}$ and CL (from tip of rostrum to posterior margin of carapace; Jadamec et al. 1999, their Fig. 21, p. 29) and estimated total length of Pereiopod 2 (P2TL) by summing the length of its merus (M2L), carpus (C2L), propodus (P2L) and dactyl (D2L) (Jadamec et al. 1999, their Fig. 14, p. 20). Maximum span was estimated as $\mathrm{CW}+2 \times \mathrm{P} 2 \mathrm{TL}$. Usually the legs of living snow crab are not fully extended. Instead the carpus, propodus and dactyl of each leg are either parallel to the longitudinal axis of the body or oriented inward. Hence, width at rest was estimated as CW $+2 \times$ M2L. Likewise, neglecting the very short Pereiopod 5, the span of a snow crab at rest observed from the side consists mostly of the CL and the propodus of Pereiopod 2 projecting forward. The chela position is variable, but rarely extends past the tip of the propodus of Pereiopod 2. Therefore, length at rest was estimated as CL + P2L.

Because snow crab is sexually dimorphic, males and females were treated separately. Maturity status was assessed by chela and abdomen allometry for males and females, respectively (Sainte-Marie et al. 1995, Alunno-Bruscia \& Sainte-Marie 1998). In males, the onset of sperm production changes the growth rate of chela and possibly other pereiopods relative to carapace. Consequently sub-adult males were further divided into immature ( $<37 \mathrm{~mm} \mathrm{CW})$ and adolescent ( $\geq 37 \mathrm{~mm} \mathrm{CW}$ ) males according to Sainte-Marie et al. (1995). Similarly, sub-adult females were divided into 2 groups on the basis of abdomen allometry following Alunno-Bruscia \& Sainte-Marie (1998): small (17 to $42.4 \mathrm{~mm} \mathrm{CW}$ ) and large ( $\geq 42.5 \mathrm{~mm} \mathrm{CW})$ prepubescent females.

During February 2006, gape width and height were measured on 18 anesthetized cod (42.6 to $76.9 \mathrm{~cm}$ FL).
These fish were held captive in the aquaculture facilities of the Maurice Lamontagne Institute for 1 to $2 \mathrm{yr}$ prior to these measurements. In addition, F. Scharf (University of North Carolina at Wilmington) graciously provided us with measurements of gape width for 18 other fish (30 to $91 \mathrm{~cm} \mathrm{FL).} \mathrm{He} \mathrm{measured} \mathrm{total}$ length, but there is little difference between fork and total length in cod, and we did not attempt to correct his measurements.

Data analysis. The abundance of snow crab in the diet of a sample of cod was evaluated using 3 measures. A partial fullness index ( $\mathrm{PFI}$; Lilly 1991) for snow crab was calculated as:

$$
\mathrm{PFI}=\frac{1}{n} \sum_{j=1}^{n} \frac{\mathrm{SCM}_{j}}{L_{j}^{3}} \times 10^{4}
$$

where $\mathrm{SCM}_{j}$ is the mass (in g) of snow crab in fish $j_{1} L_{j}$ is the fork length (in $\mathrm{cm}$ ) of fish $j$, and $n$ is the number of cod in the sample. Contribution in mass was calculated as:

$$
\% \text { mass }=\frac{100}{n} \sum_{j=1}^{n} \frac{\mathrm{SCM}_{j}}{\mathrm{SM}_{j}}
$$

where $\mathrm{SM}_{j}$ is mass (in $\mathrm{g}$ ) of stomach content of fish $j$. Finally, frequency of occurrence (FO) was calculated as:

$$
\mathrm{FO}=\frac{n_{S C}}{n}
$$

where $n_{\mathrm{SC}}$ is the number of stomachs containing snow crab.

Snow crab contribution to the diet was calculated in 2 ways for each $5 \mathrm{~cm}$ length class of cod: first by using all stomachs in each sample and second by excluding empty stomachs. For the former, the percent mass was forced to zero for empty stomachs to avoid the division by zero.

The relationships between minimum, median and maximum prey size as a function of predator size was determined by quantile regression $(\tau=0.01,0.5$ and 0.99 , meaning that 1,50 and $99 \%$ of the data points were situated below the fitted line, respectively) fitted to the snow crab CW $\times$ cod FL data (Scharf et al. 1998, Cade et al. 1999) using R v. 2.2 (R Development Core Team 2005) and the $R$ package quantreg (Koenker 2005).

The frequency distribution of $\mathrm{CW}$ of ingested snow crabs was plotted to identify the relative contribution of each instar to cod diet (instars are described by Lovrich et al. 1995). The size of snow crab ingested by cod in the NGSL and SGSL was compared by the Wilcoxon 2-sample test (Sokal \& Rohlf 1995) using JMP (SAS Institute Inc. 2003).

After logarithmic transformation, snow crab and cod allometric relationships were analyzed by linear regression using R v. 2.5. Slopes of the relationships for 
different categories of snow crab ( 3 male and 3 female categories) were compared by ANOVA followed, if necessary, by multiple comparisons of slopes (Sokal \& Rohlf 1995, p. 501, Tukey-Kramer, Gabriel's approximate method). Categories with homogeneous slopes were then compared by ANCOVA (Sokal \& Rohlf 1995). Type II regressions are usually favoured for allometric regressions (Ricker 1973, Isobe et al. 1990), but the 2 types of regressions are very similar when $\mathrm{r}^{2}$ is high (Isobe et al. 1990, Trussell 1997), which was the case here. Hence, we used Type I regressions to easily compare slopes or intercepts.

\section{RESULTS}

\section{Predator-prey relationship between snow crab and cod}

The importance of snow crab Chionoecetes opilio in cod Gadus morhua diet was influenced by cod size in both the NGSL and SGSL, using all 3 measures of snow crab abundance (Table 1). The proportion of snow crab in the cod diets was quite low, never exceeding $10 \%$ of stomach content mass for any cod size class. Cod $<20 \mathrm{~cm}$ FL ate almost no snow crab. Contribution of snow crab to cod diet increased until 70 to $75 \mathrm{~cm}$ (SGSL) or 75 to $80 \mathrm{~cm}$ (NGSL) and then declined for larger individuals.

Ingested snow crabs ranged from $2.2 \mathrm{~mm}$ (the single megalop in our sample) to $62.4 \mathrm{~mm} \mathrm{CW}$ ( $\mathrm{n}=3293 \mathrm{crabs})$, but most ranged from 5 to $30 \mathrm{~mm} \mathrm{CW}$ (Fig. 2a). The size of ingested snow crab increased with cod length $(50 \%$ quantile regression, $\mathrm{p}<$ 0.0001 ; Fig. 2a). Maximum and minimum sizes of ingested snow crab were linearly related to cod length (99 and $1 \%$ quantile regressions, $\mathrm{p}<0.0001)$. Because there were few cod $>75 \mathrm{~cm}$ in our samples, snow crabs from cod stomachs collected in 1980 to 1982 in the SGSL were taken from 2 published studies (Waiwood \& Elner 1982, Robichaud et al. 1991) to better assess the maximum size of snow crabs eaten by large cod (75 to $114 \mathrm{~cm} \mathrm{FL)} \mathrm{(Fig.} \mathrm{2b).} \mathrm{Occasionally,} \mathrm{a} \mathrm{few}$ large male snow crabs with soft shells (i.e. recently moulted) were observed in cod stomachs by Robichaud et al. (1991), otherwise CWs of snow crabs eaten by cod in all 3

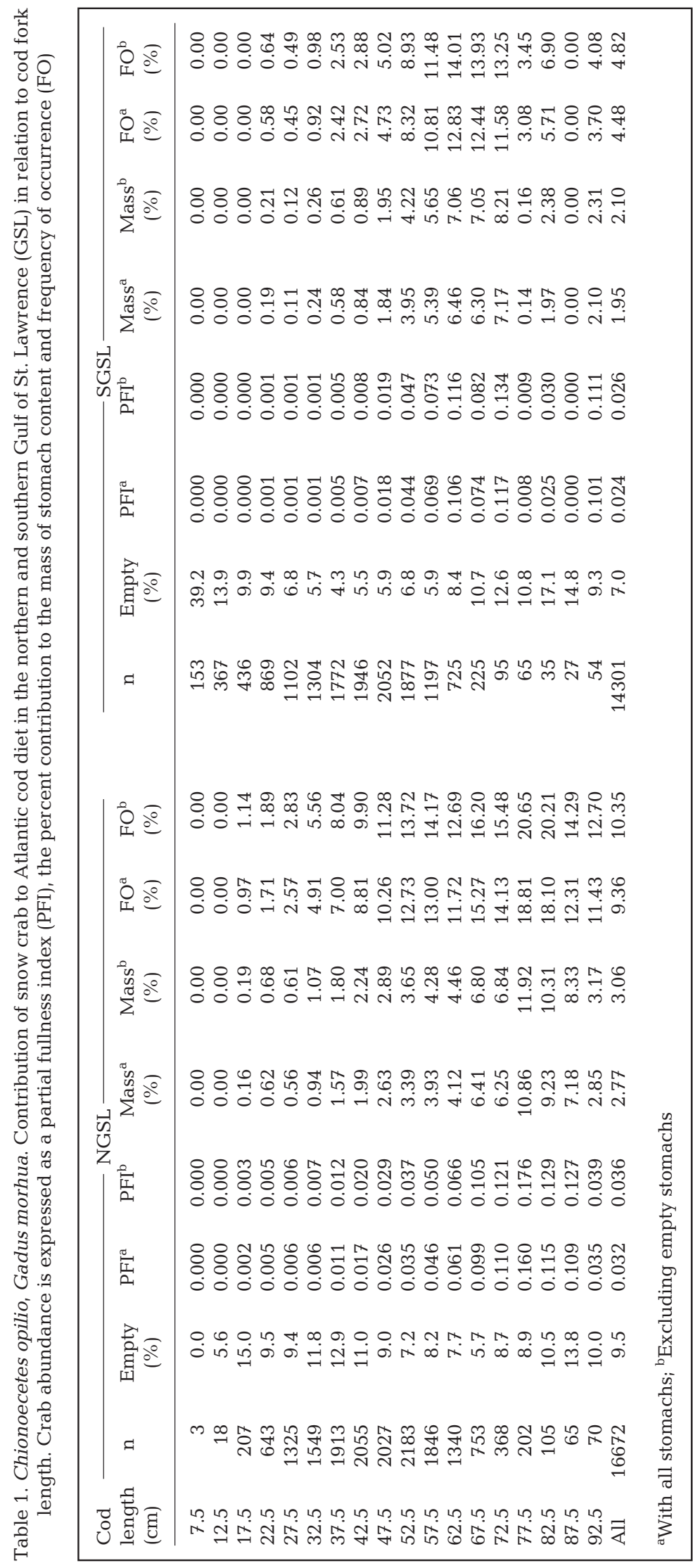




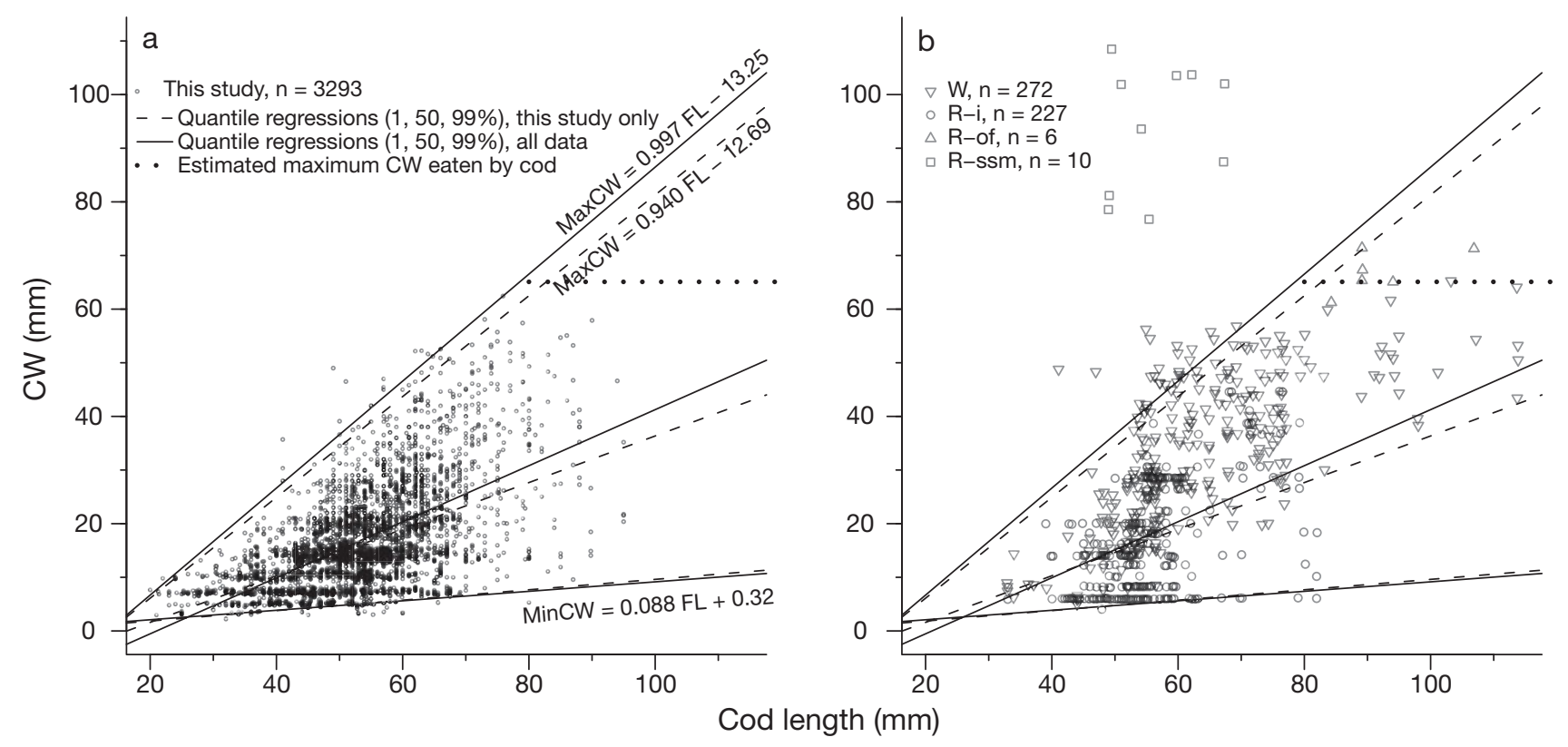

Fig. 2. Chionoecetes opilio, Gadus morhua. Relationship between prey size (snow crab carapace width [CW]) and predator size (Atlantic cod fork length [FL]): (a) present study and (b) data from published studies. W: Waiwood \& Elner (1982); R: Robichaud et al. (1991). i: immature individuals; of: ovigerous females; ssm: soft-shell males; dashed and solid lines: quantile regressions (99, 50 and $1 \%$ ) of CW as a function of cod length, calculated using only data from the present study or all 3 studies (except soft-shell males), respectively; horizontal dotted line: apparent ceiling $(65.1 \mathrm{~mm})$ in CW of hard-shell snow crabs eaten by cod

studies were strikingly similar. Quantile regressions were again significant $(99,50$ and $1 \%, \mathrm{p}<0.0001)$ when fitted to all available data for hard-shell snow crab. The additional data had no effect on the estimate of minimum CW calculated with quantile regression, but resulted in a small increase of the slope for median and maximum CW (compare solid and dashed lines in Fig. 2). However, there seems to be a ceiling in the CW of hard-shell snow crabs eaten by large cod (Fig. 2b). This ceiling was estimated at $65.1 \mathrm{~mm}$ (95\% quantile of snow crab CW in cod $\geq 80 \mathrm{~cm}$ ).

Some sizes of snow crab were more abundant than others in cod stomachs, reflecting instar composition, as indicated by the horizontal banding of CWs across cod length. This is most apparent in Fig. 2a, where a majority of crabs were measured to the nearest $0.01 \mathrm{~mm}$. For the NGSL, there were 5 clearly defined modes in the frequency distribution of ingested crabs (Fig. 3). Based on the results of other studies of snow crab in the GSL (Robichaud et al. 1989, Lovrich et al. 1995, Comeau et al. 1998, Dionne et al. 2003), these modes were assigned to Instars II to VI. Three less well defined modes showed that very small Instar I snow crabs, the first post-settlement stage, as well as Instar VII and VIII+ snow crabs were also ingested by cod. In the NGSL, immature crabs from Instars III to VI were most commonly eaten by cod, $28.9 \%$ of ingested snow crabs belonging to Instar $\mathrm{V}$ alone. In the SGSL, reso- lution of instars was not as obvious due to small crab numbers and coarseness of CW measurements. The only prominent modes corresponded to Instars VI and VII.

Crabs eaten by cod were larger in the SGSL than in the NGSL: only $10.4 \%$ of snow crabs belonged to Instars I to IV in the SGSL, compared with $37.3 \%$ in the NGSL (Fig. 3). It is known that recruitment is variable, perhaps even periodic in snow crab (Conan et al. 1996, Sainte-Marie et al. 1996, Caddy et al. 2005), so this difference in sizes eaten between the 2 regions could be due to the different sampling periods: CW was measured from 1994 to 2003 in the NGSL, but only from 1999 to 2003 in the SGSL. Therefore, the analysis was repeated using the common 1999 to 2003 sampling period for both regions. The relative abundance of sedentary snow crab was reduced to $26.0 \%$ in the NGSL, which suggests that part of the difference in the size distributions observed in both regions was due to greater abundance of small crabs in 1994 to 1998. Nevertheless, cod from the SGSL still ingested larger snow crabs than those from the NGSL (Wilcoxon test, $W=208789.5, \mathrm{p}<0.0001, \mathrm{n}=1299$ for the NGSL and 614 for the SGSL). This was not due to differences in cod size, as mean cod length $( \pm \mathrm{SD})$ differed by $<1 \mathrm{~cm}$ between the 2 regions $(53.1 \pm 10.7$ and $53.8 \pm 8.2 \mathrm{~cm}$ for the NGSL and SGSL, respectively). 


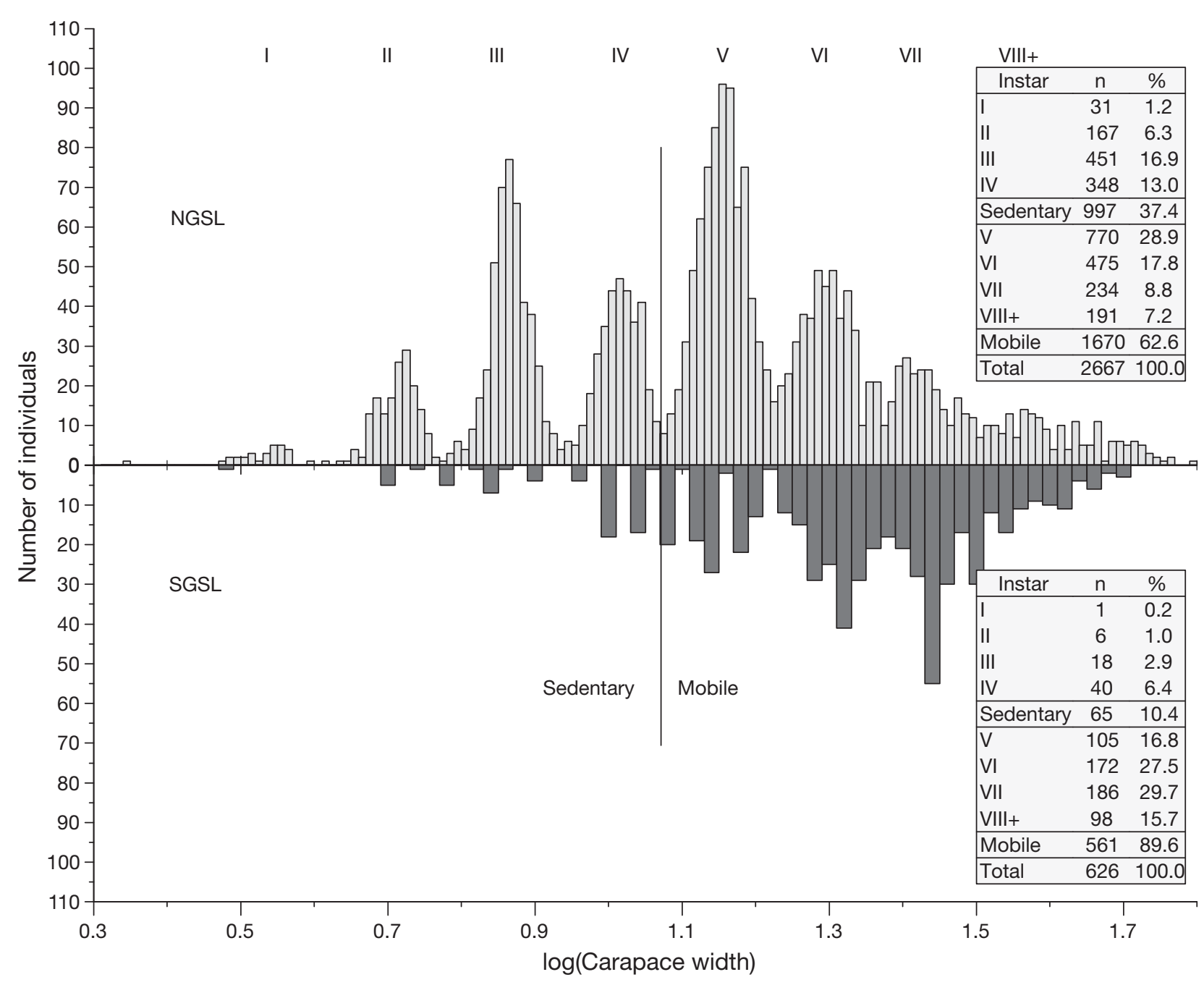

Fig. 3. Chionoecetes opilio, Gadus morhua. Size-frequency distribution of snow crabs ingested by Atlantic cod in the NGSL (upper panel) and SGSL (lower panel). Roman numerals above the modes indicate instar number. The size limit between sedentary (Instars I to IV) and mobile (Instars V to VIII) crabs $(11.75 \mathrm{~mm}$ ) is indicated by a vertical line. Note wider bins for SGSL to reflect coarseness of CW measurements

\section{Morphometric measurements on snow crab and cod}

The regressions between total length of Pereiopod 2 and CW (after logarithmic transformation) of the 6 categories of snow crab did not share a common slope $\left(F_{5,136}=6.59, \mathrm{p}<0.0001\right)$. Post hoc comparisons of slopes revealed that slopes were steeper for large males than for most other categories of snow crab (Fig. 4a). The remaining categories (immature males, small and large pre-pubescent females, adult females) did not differ in slope $\left(F_{3,71}=1.31, \mathrm{p}=0.28\right)$ or in intercept $\left(F_{3,74}=1.90, \mathrm{p}<0.14\right)$, and a single regression was fitted to these data. The length of Pereiopod 2 was negatively allometric to CW for these categories of snow crab (common slope [95\% CI]: 0.86 [0.83 to 0.89]). Large males had a common slope $\left(F_{1,65}=2.33\right.$, $\mathrm{p}=0.13)$, but the intercept was greater for adult than for adolescent males $\left(F_{1,66}=84.46, p<0.0001\right)$. The length of Pereiopod 2 was positively allometric to CW in adolescent and adult males (slope: 1.05 [1.02 to 1.08]).

There was a very close relationship between CL and CW (Fig. 4b), although small but significant differences existed among the regressions for the 6 categories of snow crab. The overall comparison of the 6 regressions revealed differences among slopes $\left(F_{5,110}=\right.$ 4.87, $\mathrm{p}=0.0004)$. In post hoc comparisons, slopes for adolescent and large males were steepest. When adolescent and adult males were compared, slopes $\left(F_{1,56}=1.27, \mathrm{p}=0.26\right)$ and intercepts $\left(F_{1,57}=0.05, \mathrm{p}=\right.$ $0.83)$ were similar. Therefore, a single regression was fitted to all large male snow crab. CL was negatively 


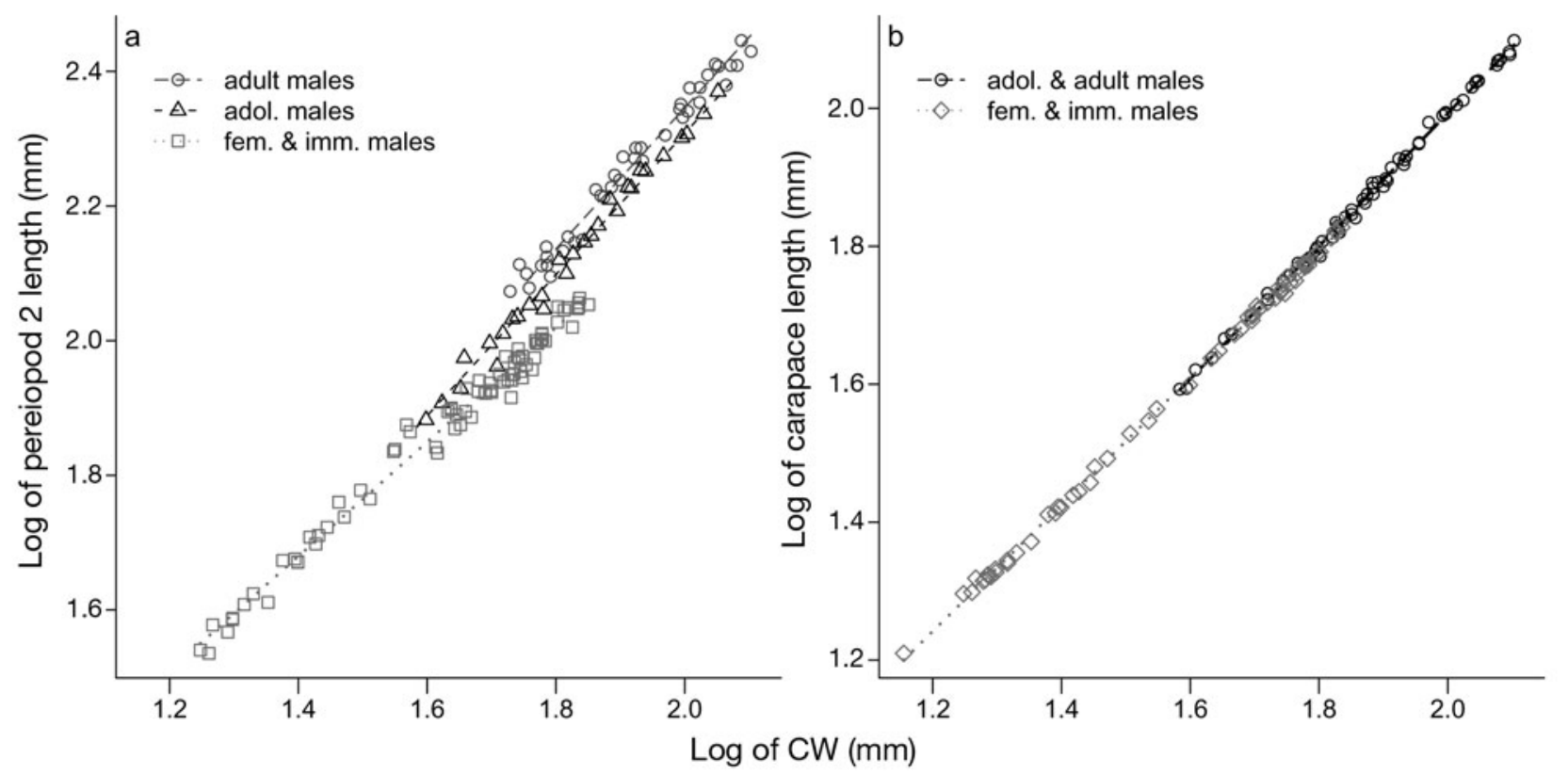

Fig. 4. Chionoecetes opilio. Allometric relationship between CW and (a) total length of Pereiopod 2 and (b) carapace length for categories of snow crab that differed significantly in either slope or intercept for these relationships. adol.: adolescent; fem.: female; imm.: immature

allometric to $\mathrm{CW}$ for these crabs (slope: 0.96 [0.95 to 0.98]). Slopes of the remaining categories (immature males, small and large pre-pubescent females, adult females) did not differ $\left(F_{3,54}=0.67, \mathrm{p}=0.57\right)$, but the intercepts were not all equal $\left(F_{3,57}=4.00, \mathrm{p}=0.012\right)$. Considering that Tukey-Kramer tests did not reveal significant differences among these snow crab categories, females together with immature males were regrouped and fitted with a single regression. CL was also negatively allometric to $\mathrm{CW}$ for female and immature male snow crab (slope: 0.92 [0.91 to 0.93]). It is not clear whether this small, but statistically significant, difference in the regressions of CL on CW for large male snow crabs and females plus immature males is meaningful for the biology of snow crab, but it is clearly of no consequence for the perception of prey length by cod predators, and a single relationship was used for all categories of snow crab in modelling length at rest.

The coefficients of the allometric relationships relating length of Pereiopod 2 and of segments of Pereiopods 2, as well as of CL, to snow crab CW for categories of snow crab that differed in either slope or intercept are provided as Table A4 (available at www.int-res. com/articles/suppl/m363p227_app.pdf).

There was a linear relationship between gape width and cod length (log-transformed data; Fig. 5, $F_{1,33}=$ 836, $\left.\mathrm{p}<0.0001, \mathrm{r}^{2}=0.96\right)$. Because the slope was $>1$ $(1.389,95 \% \mathrm{CI}=1.29$ to 1.49$)$, gape width was proportionally greater in large than in small cod. This relation-

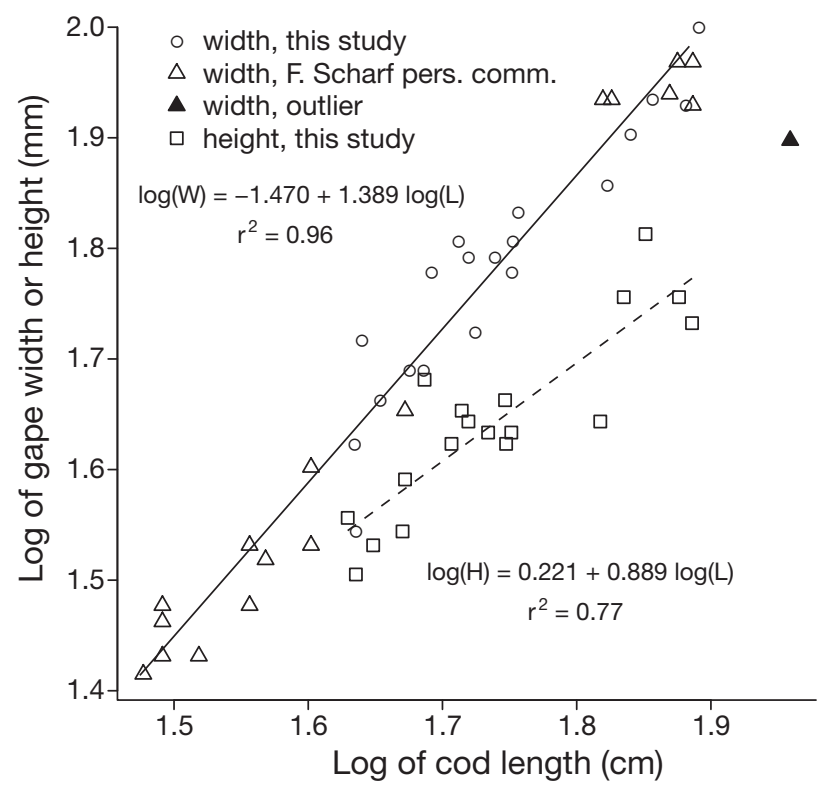

Fig. 5. Gadus morhua. Gape width and height as a function of body length in Atlantic cod, combining fish measured in the present study and those measured by F. Scharf (University of North Carolina at Wilmington, pers. comm., March 2006). One fish was excluded from the regression because it was clearly different from the others, either because of measurement error or malformation

ship was obtained after pooling cod measured in the present study with those measured by F. Scharf (no difference in slope, $F_{1,31}=0.01, p=0.98$, or in intercept, 
$\left.F_{1,32}=0.08, \mathrm{p}=0.78\right)$. The quality of fit of this relationship and the fact that cod measured in 2 different stocks by different workers were so similar suggest that our results are representative of Atlantic cod in general despite the small sample size. Gape height, measured in $18 \mathrm{cod}$, was also linearly related to cod length, but was always smaller than gape width (Fig. 5).

Morphometric measurements from snow crab and cod were combined to assess the possible causes of the upper limit in CW of snow crab ingested by cod (Fig. 6). The top of the light grey area represents cod gape width; therefore, the light grey area shows prey sizes that fit within the predator's gape, assuming this was the constraint on the predator's part. This is a reasonable assumption when the prey is snow crab, because snow crab span and length are greater than height. The dark grey zone shows snow crab CW actually observed in cod stomachs, according to the relationships described in Fig. 2. The possibility of a plateau in CW of snow crab consumed by large cod is also shown. The maximum CW of snow crab ingested by cod was clearly smaller than cod gape width. On the other hand, because of their very long legs, all but the

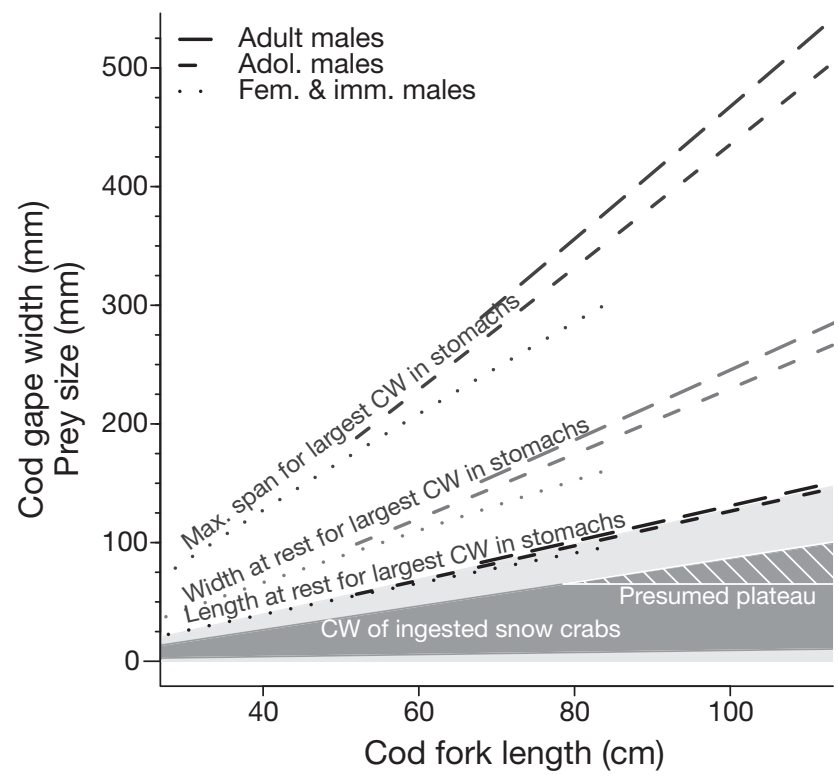

Fig. 6. Chionoecetes opilio, Gadus morhua. Cod gape width (light grey zone) and CW of snow crab found in cod stomachs (dark grey zone) as a function of cod size. Three other measures of crab size are also shown (from top to bottom): maximum span, width at rest and length at rest, corresponding to the maximum $\mathrm{CW}$ found in cod stomachs at a given cod length. These relationships are given for adult males, adolescent (adol.) males, and immature (imm.) males together with pre-pubescent and adult females (fem.). Plateau: the relationship between maximum CW of snow crabs eaten and cod length appears to fall apart for cod $>80 \mathrm{~cm}$, as no snow crabs with CW $>65$ to $70 \mathrm{~mm}$ were found, even after pooling results from 3 studies to increase the number of stomachs from large cod smallest $(<25 \mathrm{~mm} \mathrm{CW})$ snow crabs were too wide to be ingested by cod if their second pair of pereiopods was extended, e.g. their maximum span was much greater than cod gape width. In resting position, crab width still exceeded cod gape width: only cod $>80 \mathrm{~cm}$ had a gape that allowed ingestion of snow crab with $>37 \mathrm{~mm}$ $\mathrm{CW}$ if width at rest was the limiting factor. Length at rest was the snow crab dimension most closely related to cod gape width.

\section{DISCUSSION}

\section{Cod and snow crab predator-prey size relationship}

Larger prey mean greater energy intake. This comes at a cost to the predator. Larger fish prey can be more difficult to catch and necessitate longer handling times (Scharf et al. 2003). These authors concluded that fish prey of intermediate size are more profitable to the predator. Although there are certainly differences between fish and invertebrate prey in regard to antipredator strategy, it appeared that snow crab Chionoecetes opilio of intermediate size were also more profitable for cod Gadus morhua of a given size compared with smaller or larger crab, as shown here by the fact that the $50 \%$ quantile regression between $\mathrm{CW}$ of ingested snow crab and cod length was located half way between the 1 and $99 \%$ quantile regressions. Furthermore, the most often eaten sizes of snow crab were larger for larger cod, as shown here by the positive slope of this $50 \%$ quantile regression, because predator-prey size relationships are based on relative size (Scharf et al. 2003). In contrast, Arnott \& Pihl (2000) found no relationship between handling time and relative prey size for 1 yr old cod (23 to $29 \mathrm{~cm}$ FL) preying on the green crab Carcinus maenas. Profitability increased with crab size up to the maximum size eaten by cod, and wild cod selected for the largest possible crab size. Yet, relative prey sizes were very similar between Arnott \& Pihl (2000) and our study (0.03-0.09 for C. maenas vs. 0.01-0.06, $0.01-0.07$ and $0.01-0.08$ for C. opilio eaten by 30,50 and $70 \mathrm{~cm}$ cod, respectively, according to the 1 and $99 \%$ quantile regressions of Fig. 2). The relatively shorter pereiopods of C. maenas compared to $C$. opilio likely explain the low handling time for large C. maenas prey; Arnott \& Pihl (2000) suggested that the rounded shape of $C$. maenas facilitated swallowing by cod. By comparison, we suggest below (this section) that the angle of attack becomes important for cod to ingest the largest snow crab allowed by their gape width. There may also be differences in the antipredator strategies of both crab species that increase handling time for snow crab that arre large relative to the size of cod predators. 
The $99 \%$ quantile regression is of particular interest because it delineates snow crab vulnerability to predation by cod. Mouth size of predators is usually the main factor limiting prey size. The relationship between body height of ingested fish and cod size is similar to the relationship between cod mouth height and cod size, suggesting mouth height limits the size of fish that cod can ingest (Scharf et al. 2000). We determined that gape width is more relevant for snow crab prey because snow crab width and length are greater than their height. Because gape width is greater than gape height (Fig. 2; also Fig. 5 in Scharf et al. 2000), cod cannot increase effective gape by turning on their side to swallow snow crab. Maximum $\mathrm{CW}$ of ingested crabs was much less than gape width for any given cod length, presumably because overall size of snow crab was much greater than the carapace dimensions alone. Of the measures of snow crab size examined, only crab length at rest had a similar slope and intercept to the relationship between gape width and cod size. We propose that although cod can ingest small hard-shell snow crabs from any angle of attack as long as crabs are in a resting position, the ingestion of the largest hard-shell snow crabs observed in cod stomachs requires an attack from the side. Thus, length at rest determines the maximum size of snow crab that can be ingested for a given gape width.

Our data suggest a plateau in the maximum CW of hard-shell snow crabs ingested by cod. In principle, a $110 \mathrm{~cm}$ cod could ingest hard-shell snow crabs up to $96 \mathrm{~mm} \mathrm{CW}$, thereby including adolescent and adult males. But the largest hard-shell snow crab found in cod stomachs in the 3 GSL studies was 62.4 to $71.3 \mathrm{~mm}$ CW (Waiwood \& Elner 1982, Robichaud et al. 1991, present study). This apparent plateau could be due to the relatively small number of crabs eaten by large cod in the 3 studies. The small number eaten is partly the result of large cod being mostly piscivorous (Lilly 1991, Hanson \& Chouinard 2002, Link \& Garrison 2002), but may also reflect the fact that few $\operatorname{cod}>100 \mathrm{~cm}$ FL were caught despite intensive sampling efforts. Nevertheless, we think the upper size limit was not simply the result of the fewer data for very large cod. Ingested hard-shell snow crabs $>60 \mathrm{~mm}$ CW examined by Robichaud et al. (1991) were females, and the plateau at about $65 \mathrm{~mm} \mathrm{CW}$ corresponds with the usual largest sizes of adult females in the GSL (about 70 to $80 \mathrm{~mm}$; Alunno-Bruscia \& Sainte-Marie 1998). We suggest the exclusion of hard-shell adolescent and adult males from cod stomachs is due to behavioural differences between categories of snow crab. While females and immature males remain stationary or flee when approached by divers, adult males face them and adopt an aggressive stance with the second pair of pereiopods fully extended, the chelipeds held high and far apart, and the body lifted well above the bottom (Ivanov 1997, B. Sainte-Marie field obs.; see also Fig. A1 in Appendix 1, available at www.int-res.com/articles/ suppl/m363p227_app.pdf). We suspect adult male snow crabs react to approaching cod in the same manner and become invulnerable to cod predation: maximum span far exceeded cod gape width in our data. It is not known if adolescent males exhibit the same antipredator behaviour, but their absence from cod stomachs suggests that they might. Finally, the only large adult male snow crabs observed in cod stomachs had moulted recently, had a very soft shell and had been eaten whole, being 'compacted into a pliable ball in the stomach' (Robichaud et al. 1991, p. 671). Newly moulted snow crabs do not confront danger, but they tend to hide or move away (B. Sainte-Marie field obs.). A very soft carapace obviously changes the mechanical constraints involved in ingesting snow crab. Pacific cod Gadus macrocepahlus are known to eat much larger soft-shell adult female red king crab Paralithodes camtschaticus during the moulting season than the size of hard-shell red king crabs they normally eat (Blau 1986).

Predation by cod on large adolescent and adult snow crabs is likely rare or episodic in the GSL, and restricted to soft-shell individuals. The window of opportunity for cod to eat large soft-shell male snow crabs is short, because snow crabs are very soft for only the first 2 postmoult stages, which last only $0.8 \pm 0.6$ (mean \pm SD) and $6.7 \pm 6.8 d$, respectively (Hébert et al. 2002). Our own observations suggest that crab is 'pliable' only during the first post-moult stage, and are brittle rather than soft in the second stage. Therefore, large male snow crabs are vulnerable to predation by cod for 7 or $8 \mathrm{~d}$ at most, and more likely for a few hours only. Even so, cod could be an important source of mortality for large soft-shell male crab if there were a large overlap between predator and prey distributions, as is seen for Pacific cod preying on soft-shell female red king crab in the eastern Bering Sea (Blau 1986). However, there is little overlap between the distributions of Atlantic cod and large moulting male snow crab distributions in the GSL. Snow crabs usually migrate to shallow waters $(<35 \mathrm{~m})$ to moult in the GSL (Lovrich et al. 1995 and references therein), and this depth is at the shallow margin of the cod's distribution (Swain 1993, Castonguay et al. 1999). Moreover, cod size and depth are related and waters $<35 \mathrm{~m}$ deep are inhabited by smaller cod $(<40 \mathrm{~cm}$; Swain 1993, Hanson 1996) that are less likely to consume large snow crabs, even if soft. The seasonal snow crab migration may represent a strategy that allows it to find refuge from predation and cannibalism (Lovrich et al. 1995 and references therein). Finally, large males moult from March to June in the NGSL (Sainte-Marie \& Hazel 1992, Lovrich et al. 1995) and from February to 
April in the SGSL (Hébert et al. 2002), when most cod are outside the GSL (Hanson 1996, Ouellet et al. 1997, Comeau et al. 2001). A low incidence of large soft-shell male snow crabs in cod stomachs from the SGSL was confirmed by the analysis of 1887 additional cod stomachs collected from April to June of 2000 to 2003 (J. M. Hanson unpubl. data). None of the 920 stomachs from cod $<45 \mathrm{~cm}$ FL contained large soft-shell male snow crab. The 677 stomachs of larger cod collected in the eastern part of the SGSL contained 6 soft-shell snow crabs $\geq 79 \mathrm{~mm} \mathrm{CW}$ (incidence $=0.9 \%$ ). A further 4 stomachs contained soft legs from large crabs (total incidence $=1.5 \%$ ). This is the same location where the observations of Robichaud et al. (1991) were made and where the overlap between cod and soft-shell male snow crab is expected to be greater because cod return there first during the spring migration back into the SGSL. Indeed, the incidence of large, soft-shell snow crab was lower in the stomachs of large cod collected in the western part of the SGSL: only the legs of 3 large snow crabs were found in 290 stomachs (incidence rate $=1 \%$ ).

Very small snow crabs (Instar I) were virtually absent from the stomachs of even the smallest cod in our samples. However, most stomachs were collected before megalopa settled and moulted into Instar I snow crab, which occurs from August through late autumn in the GSL (Lanteigne 1985, Robichaud et al. 1989, Lovrich et al. 1995, Comeau et al. 1998). Only $20.5 \%$ of sets and $23.5 \%$ of stomachs were sampled in October or later in the NGSL. Similarly, $5.1 \%$ of sets and $10.7 \%$ of stomachs were sampled in or after October in the SGSL (Table A3 in the Appendix), when the migration of cod out of the area already is well underway (Hanson 1996, Comeau et al. 2001). Therefore, it is possible that the scarcity of Instar I snow crab in cod stomachs simply reflected low availability to cod because of lack of temporal overlap. Geographic overlap is an unlikely issue, at least in the NGSL, because large numbers of Instar III snow crabs, which appear in the same locations as Instar I crabs (Lovrich et al. 1995), were eaten by cod. However, other causes cannot be ruled out. Cod detect their prey by visual and olfactory cues, but are poor at detecting buried prey (Brawn 1969). Snow crabs bury themselves in sediment or hide beneath debris (Robichaud et al. 1991, Lovrich et al. 1995, Dionne et al. 2003); thus, cod may have difficulty locating them (Robichaud et al. 1991) or ignore them because of their small energetic return relative to the energy expended in capture.

\section{Regional differences}

The low representation of very small snow crab in cod stomachs from the SGSL, compared to the NGSL, could result from differences in spatial/temporal overlap between Instar I to $\mathrm{V}$ snow crabs and cod in both regions. For instance, Instars III and V are produced by late-summer moults in the GSL (SainteMarie et al. 1995, Alunno-Bruscia \& Sainte-Marie 1998), and a smaller proportion of stomach samples were collected in late autumn in the SGSL than in the NGSL (Table A3 in Appendix). Interactions between topography and oceanographic conditions, mainly currents, may also result in more localised settlement of megalopa in the SGSL than in the NGSL, and therefore less spatial overlap between sedentary snow crab and cod. Unlike Waiwood \& Elner (1982) and the present study, which collected cod stomachs over much of the SGSL, Robichaud et al. (1991) collected stomachs only in the eastern part of the SGSL and they found a large proportion of Instar II and III snow crab in cod stomachs. This suggests that snow crab megalopa settle in large numbers in the eastern part of the SGSL.

Dionne et al. (2003) reported that in spring (May), small sedentary snow crab were most abundant in 2 depth strata, where temperature was 0 to $1^{\circ} \mathrm{C}$, both above (18 to $27 \mathrm{~m}$ ) and below ( 85 to $105 \mathrm{~m}$ ) the colder centre of the cold-intermediate layer (CIL) (27 to $85 \mathrm{~m}$ ). Although the exact depths may vary with location, it is likely that successful settlement and the presence of sedentary snow crab also occur above and below the coldest part of the CIL in the rest of the GSL as well, because these strata correspond to cold (but not excessively cold) temperatures year-round, an advantage for a stenothermic species such as snow crab (Lovrich et al. 1995, Dionne et al. 2003). In the NGSL, most cod stomachs were collected below $80 \mathrm{~m}$, whereas the reverse was true for the SGSL (D. Chabot \& J. M. Hanson unpubl. data). It is therefore likely that sedentary snow crab and cod overlapped mostly in the deeper of these 2 strata in the NGSL, and only in the upper stratum in the SGSL. In the SGSL, cod probably encountered small snow crabs in zones where alternate prey were abundant. Hyas spp. are most abundant in shallow waters and are preferred by cod over Chionoecetes opilio (Robichaud et al. 1991, Hanson \& Chouinard 2002). Many shrimp species associated with the CIL are abundant in the SGSL and are preyed upon by cod (Hanson \& Chouinard 2002). As the deeper stratum simply does not exist in the SGSL, the relatively low abundance of Instar I to V snow crab in cod stomachs from the SGSL is likely a real phenomenon, except in zones where settlement is concentrated, as was postulated above for the eastern part of the SGSL. In the NGSL, cod can frequent coastal zones that were not covered by the research surveys. Possibly, cod in these shallower waters have a lower proportion of very small snow crabs in their diet than the cod sampled in our study. 


\section{Top-down versus bottom-up ecosystem effects}

It has been suggested that cod predation controls snow crab populations to some extent (Bailey 1982, Tremblay 1997). In the extreme, some authors have invoked a strong top-down control (Worm \& Myers 2003, Frank et al. 2005). For instance, Fig. 2 in Worm \& Myers (2003) shows a sharp negative relationship between cod and snow crab landings for the northwest Atlantic. This figure is deceiving in that it reflects a state of no or very limited fishing effort for snow crab in the pre-1980 period rather than lack of crabs (SainteMarie et al. 1996, Caddy et al. 2005). Fig. 1 in Frank et al. (2005) also shows a decline in groundfish biomass in recent years that was accompanied by an increase in snow crab catch rate per unit effort, this time for the eastern Scotian Shelf. These inverse relationships were interpreted as evidence of top-down control (predation release). Both relationships suggest a short time lag between cod decline and crab increase in abundance, as if cod preyed upon large male snow crab. Our results clearly demonstrate that cod predation is almost entirely directed at small, immature snow crabs: $80 \%$ of snow crabs ingested by cod were Instars I to VI in the NGSL and Instars I to VII in the SGSL. Similarly, cod target mostly immature snow crab on the eastern Scotian Shelf (Bundy \& Fanning 2005, their Tables B1 \& B2) and in the eastern Bering Sea (Livingston 1989, Orensanz et al. 2004).

The present study shows that hard-shell snow crabs are not likely to be eaten by cod once they are $\geq 4.5 \mathrm{yr}$ post-settlement (Instar VIII+, 31.7 to $62.4 \mathrm{~mm} \mathrm{CW}$ ), according to growth models established for the GSL (Sainte-Marie et al. 1995, Alunno-Bruscia \& SainteMarie 1998, Comeau et al. 1998). This also means that cod can feed mostly on 4 cohorts (Instars II to III, IV to V, VI and VII). Considering that most male snow crabs are available to the spring fishery 9.7 to $11.7 \mathrm{yr}$ postsettlement (Sainte-Marie et al. 1995, Comeau et al. 1998), changes in consumption of immature snow crab by cod should influence the catch rates/landings approximately 6 to $11 \mathrm{yr}$ later in the GSL. There is some evidence supporting this possibility in the SGSL, as Bailey (1982) found a negative correlation between the abundance of commercial-size snow crab and the abundance of cod 3 to $6 \mathrm{yr}$ previously. More recently, Caddy et al. (2005) found a significant correlation of -0.66 between cod abundance and commercial landings of snow crab lagged by $10 \mathrm{yr}$ in the SGSL.

Nevertheless, the effect of cod predation on crab abundance relative to other sources of variability appears to be low in the GSL as multiyear periods of both high and low abundance of young instars are known or inferred to have occurred before and after (Sainte-Marie et al. 1996, Caddy et al. 2005) the col- lapse of the NGSL and SGSL cod stocks in the early 1990s (Chouinard \& Fréchet 1994). The wide swings in year-class strength are currently attributed to intrinsic (egg production, cannibalism) (Conan et al. 1996, Sainte-Marie et al. 1996, 2002, Caddy et al. 2005) and/or physical controls (egg and larval survival) (Tremblay 1997, Sainte-Marie \& Gilbert 1998, Rosenkranz et al. 2001, Orensanz et al. 2004, Zheng \& Kruse 2006). Similarly, strong year classes of both snow crab and Pacific cod have co-occurred in the Bering Sea, and cod is not considered to have much impact on snow crab population dynamics there either, despite preying quite heavily on young instars (Zheng \& Kruse 2006). Periods of high consumption of snow crab by cod appear to occur when there are large peaks in abundance of young instars on the bottom (Waiwood \& Elner 1982, D. Chabot unpubl. data), suggesting that cod take advantage of increased availability of snow crab. Thus, predation by cod may dampen increases in abundance of adult crabs resulting from recruitment waves, i.e. many years of successful settlement (Sainte-Marie et al. 1996), although this effect must be presently weak given the very low abundance of cod in both GSL stocks. Predation by cod is also expected to have a more pronounced impact on snow crab abundance at the common edge of the distribution of both species, where water is sufficiently cold for snow crab and yet sufficiently warm for cod. For instance, Orensanz et al. (2004) suggested that a warming trend has resulted in the northward reduction of the snow crab distribution in the eastern Bering Sea, accompanied by the northward extension of the range of cod. Even though waters have started to cool again, snow crab has not spatially expanded southward. These authors proposed 2 mechanisms that prevented the reestablishment of snow crab in the southern part of the area: the current patterns prevent southward advection of larvae and new recruits are kept in check by the cod predation.

Ultimately these findings should be coupled to cod abundance data and to gastric evacuation or bioenergetic models, to allow the estimation of snow crab consumption by cod. However, recent results suggest that present evacuation models are not adequate for snow crab prey because of the long retention time of snow crab in cod stomachs (Couturier 2003). With appropriate evacuation rate models and this extensive database of cod diet, direct estimation of crab consumption by cod, including seasonal and yearly variations, will be possible.

Acknowledgements. This research was supported by the Fisheries and Oceans Canada Strategic Science Fund. We thank the many people from the Maurice Lamontagne Institute and the Gulf Fisheries Centre, who were instrumental in collecting the cod stomachs, in particular D. Archambault, 
A. Fréchet, G. A. Chouinard, P. Schwab and J. Gauthier. We also thank the crews of the vessels used for research surveys and the sentinel fishery. Special thanks to R. Miller, M. F. Beaulieu, C. Méthot, E. Dumouchel and J. Marcil, who measured the bulk of the stomach contents, and to F. Scharf for providing cod gape width data. We are grateful to the referees for their constructive comments.

Authors: Denis Chabot, Bernard Sainte-Marie, Karine Briande and John Mark Hanson for the Department of Fisheries and Oceans, Government of Canada.

\section{LITERATURE CITED}

Alunno-Bruscia M, Sainte-Marie B (1998) Abdomen allometry, ovary development, and growth of female snow crab, Chionoecetes opilio (Brachyura, Majidae), in the northwestern Gulf of St. Lawrence. Can J Fish Aquat Sci 55: 459-477

Arnott SA, Pihl L (2000) Selection of prey size and prey species by 1-group cod Gadus morhua: effects of satiation level and prey handling times. Mar Ecol Prog Ser 198: 225-238

Bailey R (1982) Relationship between catches of snow crab, C. opilio (O. Fabricus) and abundance of cod (Gadus morhua L.) in the southwestern Gulf of St. Lawrence. In: Melteff B (ed) Proceedings of the international symposium on the genus Chionoecetes. Prog. Rep. 82-10, Alaska Sea Grant College, Anchorage, AK, p 485-497

Beamish RJ, Benson AJ, Sweeting RM, Neville CM (2004) Regimes and the history of the major fisheries off Canada's west coast. Prog Oceanogr 60:355-385

Benson AJ, Trites AW (2002) Ecological effects of regime shifts in the Bering Sea and eastern North Pacific Ocean. Fish Fish 3:95-113

Bigelow HB, Schroeder WC (2002) Fishes of the Gulf of Maine. Online version of the first edition, 1953. Available at http://www.gma.org/fogm/ (accessed 15 July 2006)

Blau SF (1986) Recent declines of red king crab (Paralithodes camtschatica) populations and reproductive conditions around the Kodiak Archipelago, Alaska. In: Jamieson GS, Bourne N (eds) North Pacific workshop on stock assessment and management of invertebrates. Can Spec Publ Fish Aquat Sci 92:360-369

Brawn VM (1969) Feeding behavior of cod (Gadus morhua). J Fish Res Board Can 26:583-596

Bundy A, Fanning LP (2005) Can Atlantic cod (Gadus morhua) recover? Exploring trophic explanations for the nonrecovery of the cod stock on the eastern Scotian Shelf, Canada. Can J Fish Aquat Sci 62:1474-1489

Caddy JF, Wade E, Surette T, Hebert M, Moriyasu M (2005) Using an empirical traffic light procedure for monitoring and forecasting in the Gulf of St. Lawrence fishery for the snow crab, Chionoecetes opilio. Fish Res 76:123-145

Cade BS, Terrell JW, Schroeder RL (1999) Estimating effects of limiting factors with regression quantiles. Ecology 80: 311-323

> Castonguay M, Rollet C, Fréchet A, Gagnon P, Gilbert D, Brêthes JC (1999) Distribution changes of Atlantic cod (Gadus morhua) in the northern Gulf of St. Lawrence in relation to an oceanic cooling. ICES J Mar Sci 56:333-344

Choi JS, Frank KT, Petrie BD, Leggett WC (2005) Integrated assessment of a large marine ecosystem: a case study of the devolution of the eastern Scotian Shelf, Canada. Oceanogr Mar Biol Annu Rev 43:7-67

Chouinard GA, Fréchet A (1994) Fluctuations in the cod stocks of the Gulf of St. Lawrence. ICES Mar Sci Symp 198:121-139

Comeau LA, Campana SE, Chouinard GA, Hanson JM (2001)
Timing of Atlantic cod Gadus morhua seasonal migrations in relation to serum levels of gonadal and thyroidal hormones. Mar Ecol Prog Ser 221:245-253

- Comeau M, Conan GY, Maynou F, Robichaud G, Therriault JC, Starr M (1998) Growth, spatial distribution, and abundance of benthic stages of the snow crab (Chionoecetes opilio) in Bonne Bay, Newfoundland, Canada. Can J Fish Aquat Sci 55:262-279

Conan GY, Starr M, Comeau M, Therriault JC, Hernàndez FXM, Robichaud G (1996) Life history strategies, recruitment fluctuations, and management of the Bonne Bay Fjord Atlantic snow crab (Chionoecetes opilio). In: High latitude crabs: biology, management, and economics. Prog. Rep. 96-02, Alaska Sea Grant College, Anchorage, AK, p 59-97

Couturier C (2003) Évacuation gastrique chez la morue franche Gadus morhua: influence de la résistance du tégument de la proie. MSc thesis, ISMER, Université du Québec à Rimouski, Rimouski, QC

Davis D, Hanson JM, Watts H, MacPherson H (2004) Local ecological knowledge and marine fisheries research: the case of white hake (Urophycis tenuis) predation on juvenile American lobster (Homarus americanus). Can J Fish Aquat Sci 61:1191-1201

Dionne M, Sainte-Marie B, Bourget E, Gilbert D (2003) Distribution and habitat selection of early benthic stages of snow crab Chionoecetes opilio. Mar Ecol Prog Ser 259: $117-128$

Frank KT, Petrie B, Choi JS, Leggett WC (2005) Trophic cascades in a formerly cod-dominated ecosystem. Science 308:1621-1623

> Greene $\mathrm{CH}$, Pershing AJ (2007) Climate drives sea change. Science 315:1084-1085

Hanson JM (1996) Seasonal distribution of juvenile Atlantic cod in the southern Gulf of St Lawrence. J Fish Biol 49: 1138-1152

Hanson JM, Chouinard GA (2002) Diet of Atlantic cod in the southern Gulf of St Lawrence as an index of ecosystem change, 1959-2000. J Fish Biol 60:902-922

> Hanson JM, Lanteigne M (2000) Evaluation of Atlantic cod predation on American lobster in the southern Gulf of St. Lawrence, with comments on other potential fish predators. Trans Am Fish Soc 129:13-29

> Hébert M, Benhalima K, Miron G, Moriyasu M (2002) Moulting and growth of male snow crab, Chionoecetes opilio (O. Fabricius, 1788) (Decapoda, Majidae), in the southern Gulf of St. Lawrence. Crustaceana 75:671-702

Isobe T, Feigelson ED, Akritas MG, Babu GJ (1990) Linear regression in astronomy. I. Astrophys J 364:104-113

Ivanov BG (1997) On behaviour of some commercial crabs (Crustacea: Decapoda, Brachyura, Majidae; Anomura, Lithodidae) with special reference to snow crab (Chionoecetes opilio). Zool Zh 76:287-293

Jadamec LS, Donaldson WE, Cullenberg P (1999) Biological field techniques for Chionoecetes crabs. Alaska Sea Grant College, Fairbanks, AK

Kimura DK, Shimada AM, Lowe SA (1993) Estimating von Bertalanffy growth parameters of sablefish Anoplopoma fimbria and Pacific cod Gadus macrocepahlus using tagrecapture data. Fish Bull (Wash D C) 91:271-280

Koenker R (2005) Quantreg: quantile regression. R Package Version 3.84. R Foundation for Statistical Computing, Vienna

Koutitonsky VG, Bugden GL (1991) The physical oceanography of the Gulf of St. Lawrence: a review with emphasis on the synoptic variability of the motion. In: Therriault JC (ed) The Gulf of St. Lawrence: small ocean or big estuary? Can Spec Publ Fish Aquat Sci 113:57-90 
Lanteigne M (1985) Distribution spatio-temporelle des larves de crabe appartenant aux genres Chionoecetes et Hyas, dans la Baie des Chaleurs, Canada. MSc thesis, Université de Moncton, Moncton, NB

Lilly GR (1991) Interannual variability in predation by cod (Gadus morhua) on capelin (Mallotus villosus) and other prey off southern Labrador and northeastern Newfoundland. ICES Mar Sci Symp 193:133-146

Link JS, Garrison LP (2002) Trophic ecology of Atlantic cod Gadus morhua on the northeast US continental shelf. Mar Ecol Prog Ser 227:109-123

Livingston PA (1989) Interannual trends in Pacific cod, Gadus macrocephalus, predation on three commercially important crab species in the eastern Bering Sea. Fish Bull (Wash DC) 87:807-827

Lovrich GA, Sainte-Marie B, Smith BD (1995) Depth distribution and seasonal movements of Chionoecetes opilio (Brachyura: Majidae) in Baie Sainte-Marguerite, Gulf of Saint Lawrence. Can J Zool 73:1712-1726

Orensanz J, Ernst B, Armstrong DA, Stabeno P, Livingston P (2004) Contraction of the geographic range of distribution of snow crab (Chionoecetes opilio) in the eastern Bering Sea: an environmental ratchet? CCOFI Rep 45:67-79

Ouellet P, Lambert Y, Castonguay M (1997) Spawning of Atlantic cod (Gadus morhua) in the northern Gulf of St. Lawrence: a study of adult and egg distributions and characteristics. Can J Fish Aquat Sci 54:198-210

R Development Core Team (2005) R: a language and environment for statistical computing, V. 2.2. R Foundation for Statistical Computing, Vienna

Ricker WE (1973) Linear regressions in fishery research. J Fish Res Board Can 30:409-434

Roberson NE, Kimura DK, Gunderson DR, Shimada AM (2005) Indirect validation of the age-reading method for Pacific cod (Gadus macrocephalus) using otoliths from marked and recaptured fish. Fish Bull (Wash DC) 103: 153-160

Robichaud DA (1985) Écologie du crabe des neiges (Chionoecetes opilio) juvénile au large des côtes nord-ouest du Cap Breton, et ses interactions avec la morue (Gadus morhua) et la raie (Raja radiata). MSc thesis, Université de Moncton, NB

Robichaud DA, Bailey RFJ, Elner RW (1989) Growth and distribution of snow crab, Chionoecetes opilio, in the southeastern Gulf of St. Lawrence. J Shellfish Res 8:13-23

Robichaud DA, Elner RW, Bailey RFJ (1991) Differential selection of crab Chionoecetes opilio and Hyas spp. as prey by sympatric cod Gadus morhua and thorny skate Raja radiata. Fish Bull (Wash DC) 89:669-680

Rosenkranz GE, Tyler AV, Kruse GH (2001) Effects of water temperature and wind on year-class success of Tanner crabs in Bristol Bay, Alaska. Fish Oceanogr 10:1-12

Sainte-Marie B, Gilbert D (1998) Possible effects of changes in CIL temperature and thickness on population dynamics of snow crab, Chionoecetes opilio, in the Gulf of Saint Lawrence. Canadian Stock Assessment Secretariat Research document 98/38 Fisheries and Oceans Canada, Ottawa. Available at: http://www.dfo-mpo.gc.ca/csas/Csas/publications/ResDocsDocRech/1998/1998_038_e.htm

Sainte-Marie B, Hazel F (1992) Moulting and mating of snow crabs, Chionoecetes opilio (O. Fabricius), in shallow waters of the northwestern Gulf of Saint Lawrence. Can J Fish Aquat Sci 49:1282-1293

Sainte-Marie B, Raymond S, Brêthes JC (1995) Growth and maturation of the benthic stages of male snow crab, Chionoecetes opilio (Brachyura: Majidae). Can J Fish Aquat Sci 52:903-924

Sainte-Marie B, Sévigny JM, Smith BD, Lovrich GA (1996) Recruitment variability in snow crab (Chionoecetes opilio): pattern, possible causes, and implications for fishery management. In: International symposium on the biology, management and economics of crabs from high latitude habitats. Prog. Rep. 96-02, Alaska Sea Grant College, Anchorage, AK, p 451-478

Sainte-Marie B, Sévigny JM, Carpentier M (2002) Interannual variability of sperm reserves and fecundity of primiparous females of the snow crab (Chionoecetes opilio) in relation to sex ratio. Can J Fish Aquat Sci 59:1932-1940

SAS Institute Inc (2003) JMP, Version 5.1. Statistics and graphics guide. SAS Institute, Cary, NC

Savenkoff C, Swain DP, Hanson JM, Castonguay M and others $(2007$ a) Effects of fishing and predation in a heavily exploited ecosystem: comparing periods before and after the collapse of groundfish in the southern Gulf of St. Lawrence (Canada). Ecol Model 204:115-128

Savenkoff C, Castonguay M, Chabot D, Hammill MO, Bourdages H, Morissette L (2007b) Changes in the northern Gulf of St. Lawrence ecosystem estimated by inverse modelling: evidence of a fishery-induced regime shift? Estuar Coast Shelf Sci 73:711-724

Scharf FS, Juanes F, Sutherland M (1998) Inferring ecological relationships from the edges of scatter diagrams: comparison of regression techniques. Ecology 79:448-460

Scharf FS, Juanes F, Rountree RA (2000) Predator size-prey size relationships of marine fish predators: interspecific variation and effects of ontogeny and body size on trophicniche breadth. Mar Ecol Prog Ser 208:229-248

Scharf FS, Buckel JA, McGinn PA, Juanes F (2003) Vulnerability of marine forage fishes to piscivory: effects of prey behavior on susceptibility to attack and capture. J Exp Mar Biol Ecol 294:41-59

Scott WB, Scott MG (1988) Atlantic fishes of Canada. Can Bull Fish Aquat Sci 219:1-731

Slizkin AG (1982) Distribution of snow crabs of the genus Chionoecetes and their habitat in the northern part of the Pacific Ocean. Izv Tikhookean Nauchno-Issled Inst Ryb Khoz Okeanogr 106:26-33

Sokal RR, Rohlf FJ (1995) Biometry - the principles and practice of statistics in biological research. W. H. Freeman, New York

Squires HJ (1990) Decapod Crustacea of the Atlantic coast of Canada. Can Bull Fish Aquat Sci 221:1-552

Swain DP (1993) Age- and density-dependent bathymetric pattern of Atlantic cod (Gadus morhua) in the southern Gulf of St. Lawrence. Can J Fish Aquat Sci 50:1255-1264

> Swain DP, Chouinard GA, Morin R, Drinkwater KF (1998) Seasonal variation in the habitat associations of Atlantic cod (Gadus morhua) and American plaice (Hippoglossoides platessoides) from the southern Gulf of St. Lawrence. Can J Fish Aquat Sci 55:2548-2561

Tremblay MJ (1997) Snow crab (Chionoecetes opilio) distribution limits and abundance trends on the Scotian Shelf. J Northwest Atl Fish Sci 21:7-22

Trussell GC (1997) Phenotypic plasticity in the foot size of an intertidal snail. Ecology 78:1033-1048

Waiwood KG, Elner RW (1982) Cod predation of snow crab (Chionoecetes opilio) in the Gulf of St. Lawrence. In: Melteff B (ed) Proc Int Symp on the genus Chionoecetes. Prog. Rep. 82-10, Alaska Sea Grant College, Fairbanks, AK, p $499-520$

Worm B, Myers RA (2003) Meta-analysis of cod-shrimp interactions reveals top-down control in oceanic food webs. Ecology 84:162-173

Zheng J, Kruse GH (2006) Recruitment variation of eastern Bering Sea crabs: climate-forcing or top-down effects? Prog Oceanogr 68:184-204 